\title{
COVID-19 around the world and the Chinese strategy to cope with SARS-CoV-2
}

\author{
Muhammad Adnan Shereen ${ }^{1}$, Hafiz Ullah ${ }^{1}$, Suliman Khan ${ }^{2}$, Nadia Bashir ${ }^{1}$, Abeer Kazmi ${ }^{3,{ }^{*}}$, Kainat Saif ${ }^{4}$, \\ Muhammad Suhaib Qudus ${ }^{1}$
}

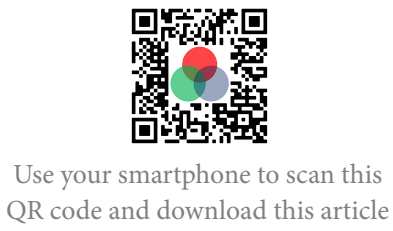

${ }^{1}$ State Key Laboratory of Virology,

College of Life Sciences, Wuhan

University, Wuhan, PR China

${ }^{2}$ The Department of Cerebrovascular Diseases, The Second Affiliated Hospital of Zhengzhou University, Zhengzhou, China

${ }^{3}$ College of life sciences, Wuhan University, Wuhan, PR China

${ }^{4}$ Faculty of Social sciences, Jinnah University for Women, Karachi, Pakistan

Correspondence

Abeer Kazmi, College of life sciences, Wuhan University, Wuhan, PR China

Email: Abeer_Kazmi@yahoo.com

History

- Received: Jun 08, 2020

- Accepted: Jul 26, 2020

- Published: Jul 31, 2020

DOI : 10.15419/bmrat.v7i7.618

\section{Check for updates}

\section{Copyright}

(c) Biomedpress. This is an openaccess article distributed under the terms of the Creative Commons Attribution 4.0 International license.

\begin{abstract}
SARS-CoV-2, a zoonotic virus, emerged in China causes Coronavirus Disease-2019 (COVID-19). Senior citizens and people with co-infections, genetic diseases, immune-compromised states, and cardiovascular diseases are at higher risk. There is no approved vaccine or drug available to treat COVID-19, although a few antivirals, interferon, and other drugs have reduced viral load in infected patients. However, these drugs have not been significantly effective in European countries. More than 40 different strains of SARS-CoV-2 have been detected in various parts of the world; they might have adapted themselves to the environmental conditions and have become resistant to therapeutic strategies. Many developed and developing countries are facing shortages of surgical masks and other protection tools. So far, the strategies developed by Chinese authorities have efficiently mitigated the SARS-CoV-2 transmission and limited mortality rate to less than $4 \%$, with more than 78,000 people recovered from COVID-19. This review article highlights the pandemic conditions in different parts of the world, as well as possible reasons behind minimal COVID-19 infections and the high mortality rates. It will discuss information about China's strategies to cope with SARS-CoV-2 which can help other countries to mitigate viral spread and infection.
\end{abstract}

Key words: SARS-CoV-2, COVID-19, BCG vaccine, Cross resistance, Chinese Strategies

\section{INTRODUCTION}

In December 2019, the Chinese government reported various cases of pneumonia with unknown etiology to the World Health Organization (WHO). On January $10^{\text {th }} 2020$, the National Health Commission of China reported the diseases as viral pneumonia, which was epidemiologically found linked with the Huanan Seafood Market in Wuhan city, known for selling live animals, such as snakes, rabbits, birds, dogs, and bats ${ }^{1}$. Later on, investigations revealed that the virus could be transmitted to humans from infected persons via aerosols or direct contact $^{2-6}$. On January $13^{\text {th }}$, Thailand, Japan, and Korea reported their first confirmed cases of SARS-CoV- $2^{1}$. From March $27^{\text {th }}$, SARS-CoV-2 became a global pandemic $^{7}$. The SARS-CoV-2 has several strains and has spread to over 210 countries and territories with 2 international conveyances worldwide, though the viral pathogenicity and its impacts are not similar in all continents and countries. As of the $23^{\text {rd }}$ of April, SARS-CoV-2 infected 15,390,252 individuals worldwide with 630,537 fatalities and 9,367,463 recoveries $^{8}$. European countries, especially Italy is facing the worst situation of their history, after World War 2. Around $65 \%$ of the Italian population is above 40 years in age; this could be the reason for the high mortality in Italy and Europe. On the other hand, countries that used Ebola vaccine or those that were part of the BCG (TB vaccine) vaccination policy are less infected and show cross-resistance against COVID19; this suggests that the previous vaccines may have produced antibodies that are effective against SARSCoV-2. We discuss the conditions of Italy, Iran, and other highly infected countries. We also summarize the Chinese strategies and techniques to mitigate and eradicate SARS-CoV-2.

\section{COVID-19 in Indo-Pak}

The Pakistani government's decision to not evacuate their nationals from China compelled anxious students and others to enter Pakistan through other routes, such as Dubai, Thailand, Malaysia, Singapore, and Bangkok. At that time, lack of proper screening, quarantine facilities, and diagnostic kits put Pakistan in critical condition. Afterwards, the Pakistani nationals returned from Iran and Saudi Arabia and reported suspected symptoms, prompting critical attention. More than 4000 suspected patients were quarantined at Taftan, Balochistan (Pakistan) with lack of proper hygiene and basic isolation facilities ${ }^{9}$. Therefore, Pakistan was at high risk, with 5,988 confirmed 
infected cases and 107 fatalities reported at the start of April; now the number of infected patients has increased to 269,191 , with 5,709 deaths (as of July $23^{\text {rd }}$ ) (Figure 1) ${ }^{7,10}$.

In India, the SARS-CoV-2 transmission escalated in mid-February, with thousands of confirmed cases reported in those who had traveling history to infected countries or were linked to infected individuals during the pandemic. The first confirmed case of COVID-19 in India was reported on the $30^{\text {th }}$ of January in Kerala state. One of the students evacuated by the Indian government, who was from Wuhan, China and had COVID-19, infected three more individuals (as reported on the $3^{\text {rd }}$ of February). Since April $14^{\text {th }}$, 11,555 people were infected in India with 405 fatalities. Now, India has become the $3^{\text {rd }}$ most infected country with 1,241,416 infected patients and 29,904 fatalities (as of July $23^{\text {rd }}$ ) (Figure 1) ) $^{7,8,11}$.

\section{COVID-19 in Iran and Saudi Arabia}

Merchants and students have been introducing COVID-19 in Iran. The first case of COVID-19 in Iran was reported in Qom on the $20^{\text {th }}$ of February 2020, and involved a merchant who had a traveling history from China to Qom. Up until the $26^{\text {th }}$ of February, the Iranian government did not impose lockdown and mosques were still open to worship. The holy shrines in Iran were also kept open for visitors which caused a rapid spread of SARS-CoV$2^{12,13}$. By the $14^{\text {th }}$ of April, the toll of infected people was 76,389 with 4777 deaths, which are now increased to 281,413 infected cases and 14,853 fatalities (Figure 1) ${ }^{8}$.

On February $27^{\text {th }}$, the Saudi government temporarily suspended the entry of nationals and other tourists to perform the Umrah pilgrimage in the Great Mosque of Mecca or to visit the Prophet's Mosque in Medina. The first case in Saudi Arab was reported on March $2^{\text {nd }}$ when an infected Saudi national returned to the country from Iran via Bahrain. The timely controlled measurements from the Saudi government mitigated the viral spread. As of April 14 ${ }^{\text {th }}, 5,862$ infected patients were recorded in Saudi Arabia with only 79 deaths. According to the recent records $\left(23^{\text {rd }}\right.$ of July), the number of COVID-19 patients increased $(258,156)$, and the recovery rate was $81.5 \%{ }^{8}$. The Arab countries have already faced MERS-CoV-2 in 2012; this could be the possible reason for the rapid recovery of COVID-19 patients in Saudi Arabia and other Arabian countries.

\section{COVID-19 in Europe}

The first two confirmed cases of COVID-19 in the UK were reported on the $31^{\text {st }}$ of January 2020, in York City where a student of York University returned from China. On February $6^{\text {th }} 2020$, a third confirmed case was reported in Brighton where a man returning from Singapore was found to be positive for COVID-19. On the $10^{t h}$ of February, the COVID-19 pandemic started spreading in the UK and, thus, the State for Health and Social Care launched the Health Protection Regulation $2020^{14}$. The overall 14-day cumulative incidence rate for Europe increased from 3.3 cases per 100,000 population to 46.1 cases per 100,000 population. There were rapidly inclining numbers of cases in European countries without epidemiological links to explain the source of transmission. The viral spread in Europe was predicted to be at the same pace as China's Hubei Province. Uncertainty still remains as to the extent of and kinds of prevention and control measures to slow the rate of transmission. Of the more than $80 \%$ of patients who recovered from the COVID-19 outbreak in China, only 6\% experienced critical illness; recent data from Europe indicate that less than $30 \%$ of cases have recovered from COVID19.

Severe illness and death are more common among the elder individuals and those with other chronic underlying conditions. The effects of mitigation measure has led to decreased transmission of COVID-19 in the general population; however, it is not possible to evacuate senior citizens. Due to lack of specific treatment for COVID-19, supportive therapy may help in recovery of patients with young age but the elderly and individuals with chronic underlying conditions may suffer. As of April $14^{\text {th }}$, the highest number of deaths from COVID-19 in Europe were reported in Italy $(20,465)$, followed by Spain $(18,056)^{7}$. The main reason behind viral transmission in Italy is late response. The Italian government kept their doors open for tourists and other nationals; they did not properly screen new arrivals at the airports nor evacuated their nationals from infected zones lacking proper quarantine procedure. On the $20^{\text {th }}$ of February, first case of COVID-19 was recorded in Italy when a 38-yearold man visited a local hospital. The health officials of Italy claimed that the virus arrived in the country before the detection of the first case ${ }^{15}$. There is no valid reason to answer the question as to why the mortality rate in Italy is so high. However, age and co-infections might be main factors since the citizens of Italy are the second oldest in the world, with $65 \%$ of Italy's population above 40 years of age. Other contributing factors include the minimal number of available hospital 


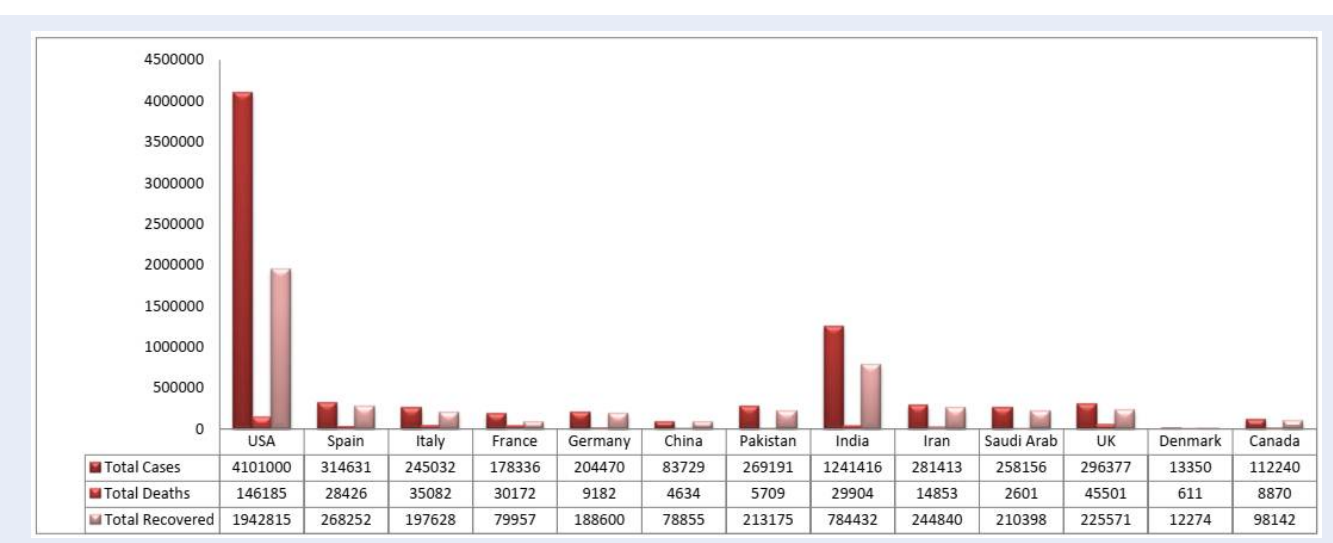

Figure 1: The status of COVID-19 pandemic around the various regions of world (Asby 23 ${ }^{r d}$ July, 2020).

beds and ventilators. As of July $23^{r d}$, the total number of infected people in Italy, Spain and the UK are 245032, 314631 and 296377, respectively (Figure 1). European countries have almost contained the viral spread; no new COVID-19 cases have been reported in the UK, Spain or Italy ${ }^{8}$.

\section{COVID-19 in USA, Denmark and Canada}

The first confirmed case of COVID-19 in the USA was reported on $19^{\text {th }}$ January 2020 when a 35-yearold man with recent history of travel from Wuhan (15 $5^{\text {th }}$ January 2020) was tested positive for COVID19 infection. The director of the National Institute of Allergy and Infectious Diseases in the USA raised his concern for the possibility of spreading COVID19 infection. However, several states were unable to provide sufficient facilities to conduct COVID19 tests $^{16,17}$. During the month of April, the scientists estimated that COVID-19 could kill 100,000 to 240,000 people in America ${ }^{7,18}$. According to recent available data, USA is the most infected country and the virus is frequently infecting and killing individuals. As of the $23^{\text {rd }}$ of July, 4,101,000 individuals have been infected with SARS-CoV-2 in the USA, with 146,185 total deaths. China, Japan, Pakistan and Korea face smog conditions every winter and, therefore, their nationals are used to wearing masks, while in the US the use of masks is prohibited and subjected to harassment. Even the American president (Donald Trump) ignored the advice from his government scientists and refused to use a mask as he is uncomfortable with it. Due to the lack of masks, the US president advised US nationals to use scarves to avoid viral spreading and to save surgical masks for doctors and other health workers ${ }^{19}$.
The first case of COVID-19 in Denmark was registered on February $27^{\text {th }}$, when a Danish journalist returned from abroad. As of April $14^{\text {th }}$, there are 6,681 confirmed cases of COVID-19 in Denmark, with 309 deaths. The Danish government took a number of measures to minimize the spread of the virus. All educational institutions, daycares and public institutions were closed; Prime Minister Mette Frederiksen strongly encouraged people to strictly follow instructions. On March $14^{\text {th }}$, the Danish government shut down their borders and all gatherings of more than 10 people were prohibited. The government has agreed to cover 75\% (per month) of employees' salaries. Employees in the public sector can work from home with no consequences to their salary. The immediate response from the Danish government efficiently contained the viral spreading and fatality rate. As of July $23^{r d}$, only 13,350 individuals were infected in Denmark with $92.3 \%$ recovery rate $^{8}$.

The first case of COVID-19 in Canada appeared on the $27^{\text {th }}$ of January, after a person returned from Wuhan to Toronto. As of April 14 ${ }^{\text {th }}$, there were 27,557 confirmed cases of COVID-19 in Canada with 954 deaths $^{7}$. Out of all 13 territories of Canada, only Nunavut is not infected. On March $16^{\text {th }}$, the Canadian government closed their borders with all countries except United States. Canadian Prime Minister Justin Trudeau's wife, Sophie Grégoire Trudeau, tested positive for the virus on March $12^{\text {th }}$, and both of them went into self-isolation. On March $28^{t h}$, she announced her full recovery while the Prime Minister announced he would remain in isolation for another two weeks to ensure he had not contracted the virus ${ }^{20}$. The Canadian government imposed a strict lockdown for several weeks in the entire country; therefore, currently, no new COVID-19 cases 
have emerged in Canada, although there were infected 112,240 individuals as of July $23^{r d}$.

\section{MUTATED STRAINS OF COVID-19 MAY BE A REASON FOR DISEASE SEVERITY}

Two distinct strains of SARS-CoV-2 have been detected around the world: an aggressive strain ('Type L') and a comparatively less aggressive strain ('Type $\left.S^{\prime}\right)^{21}$. Researchers from the School of Life Sciences and the Institute Pasteur of Shanghai, Peking University, reported that $70 \%$ of isolates exhibited type L strain, while $30 \%$ were type S strain. Although the $\mathrm{L}$ type strain is said to be the mutated strain and the $\mathrm{S}$ type strain is the ancestral version, type $\mathrm{L}$ is the form found in closely related viruses, such as TG13 ${ }^{21-23}$. The genomic analysis of isolated SARSCoV-2 genome has illustrated that variations in nucleotides have given rise to different strains. The substitution of nucleotides was detected at orf1ab (T8517C) and ORF8 region (C251T and S84L) ${ }^{21,22}$. The L type of strain was more prevalent in China during early emergence of the epidemic. The $S$ type strain is non-aggressive and might have increased in relative frequency due to weaker selective pressure. Human interventions may have placed more severe selective pressure on the L type, which might be more aggressive and spread more quickly. On the other hand, the development of new variations of the spike in COVID-19 cases have likely been due to "mutations and natural selection besides recombination" 21,23 . In most of the countries where virus spread from infected patients returning from China, they had the same strain. The strains found in infected people of India contained the identical Chinese strain ${ }^{24}$. The virus may have adapted itself to the environmental conditions in different countries, impacting the pathogenicity of the virus. This could be a reason of rapid spreading, more deaths, and lower recovery rates in Europe and the US ${ }^{25}$.

\section{REASONS FOR LOWER COVID-19 INFECTION IN SOME COUNTRIES}

The viral pathogenicity and its impacts are not similar around the world. Asian countries responded more efficiently to contain the spreading of COVID19 than most of the European countries and the USA. The rapid door-to-door detection and isolation of infected individuals also significantly mitigated the viral spreading. Common use of masks by Asian nationals, even in the absence of a known infection, also momentously reduced viral spreading. China, Japan,
Pakistan and Korea face smog conditions every winter and therefore, their nationals are used to wearing masks; meanwhile in Western countries, the use of masks is prohibited and can be subjected to harassment ${ }^{19}$. In some of the countries, especially Asian countries, the strain of SAR-CoV-2 is less pathogenic and susceptible to commonly used antivirals and interferons and thus, less numbers of people are infected with minimal mortality rate. At the end of March, the mortality rate in Italy was $11 \%$ but the mortality rate in neighboring countries, such as Germany, was just 1\%; Israel had the lowest fatality rate $(0.36 \%)$. Similarly, the SARS-CoV-2 infected less people in African countries with very minimal fatalities. The weaker traveling connections and restrictions could be the reason for lower infections in African countries. However, it can also be presumed that the Ebola vaccine, which was used against Ebola virus, may have played a role of cross-resistance against COVID-19 in Africa. In a recent study, it was reported that countries vaccinated with Bacillus Calmette-Guérin (BCG) vaccine (used against TB) have low fatality rates of COVID19. Italy, USA, Spain, Belgium and Holland were not the part of the BCG vaccination policy, while Asian countries such as China, India, Pakistan, Japan and Bangladesh are still vaccinating their newborns with BCG vaccine. This could be a predominant possible reason for the lower COVID-19 associated fatalities in Asian countries or countries that were part of the BCG vaccination policy ${ }^{26}$. These vaccines might have a role as well in cross-resistance and production of antibodies that are effective against SARS-CoV-2.

\section{PROGRESSION IN VACCINE DEVELOPMENT AGAINST SARS-COV-2}

Vaccines can be the only efficient way to treat COVID19 patients. There is currently no approved vaccines available to treat COVID-19 patients, although health workers in various regions of the world are using herbal medicines along with previously used broad spectrum antivirals and antibiotics to treat COVID19 and other post-infection complications ${ }^{27-30}$. As July $23^{r d}, 9,367,463$ COVID-19 patients around the world have successfully recovered and been discharged from hospitals ${ }^{8}$. Various pharmaceutical companies and research centers are in a race to rapidly develop an efficient vaccine against SARSCoV-2 ${ }^{6,31-35}$, with some of these vaccines entering in clinical trial phase. More than 165 vaccines around the world are being developed against SARS-CoV-2, out of which only 27 vaccines have entered human 
trials ${ }^{36}$. The American government is funding three vaccines for phase 3 trials; these include mRNA-1273 by Moderna, AZD1222 by AstraZeneca, and BNT162 by Pfizer and BioNTech ${ }^{37}$. The Chinese have developed vaccine 'PiCoVacc' which has also entered in human trial phase ${ }^{38}$.

\section{STRATEGIES USED BY THE CHINESE TO COUNTER SARS-COV-2}

A total of 82,249 individuals were infected in China out of which 77,738 have successful recovered and 3,341 have died. It was assumed that SARS-CoV-2 had a low mortality rate, but it was the efforts by the Chinese that limited the mortality rate to only $4 \%$ in China $^{7}$. The next section highlights the major strategies applied by China to contain and treat COVID-19 (Figure 2).

\section{Building of temporary hospitals and quar- antine centers}

After the confirmation of viral-induced pneumonia, the Chinese government responded quickly and took some strict actions to mitigate viral spreading. To isolate infected and suspected patients, two hospitals were built within a few days by the Chinese government in Wuhan, with the capacity of $1,000(\mathrm{Hu}-$ oshenshan Hospital) and 1,600 (Leishenshan Hospital) beds. Several other buildings and public venues were also converted into temporary hospitals and isolation wards. A total of 16 temporary hospitals were built in Wuhan to treat COVID-19 patients. Notably, 42,600 public and military medical staff from all over China was sent to the Hubei Provence to treat COVID-19 patients $^{39-41}$.

\section{Rapid detection}

The Chinese researchers immediately released genetic sequences of the SARS-CoV-2 for the detection of COVID-19. Doctors and health care workers conducted door-to-door tests for detection and the suspected patients were quarantined within the home in a separate room or shifted to the quarantine centers for 10-14 days. The Chinese command and control unit quarantined up to 50 million individuals in all infected regions ${ }^{42}$. Real-time reverse transcriptase polymerase chain reaction (rRT-PCR) was used for diagnosis but it was impossible to be used for doorto-door detection. Thus, Chinese researchers developed other strategies for accurate and rapid diagnosis of COVID-19, such as antibody-based (IgM-IgG) CT kits ${ }^{43}$ and droplet digital-polymerase chain reaction (dd-PCR), which showed promising sensitive and accurate results for the detection of SARS-CoV$2^{44}$ (Figure 2).

\section{Complete lockdown}

China locked down the epicenter of COVID19, Wuhan city and the entire Hubei Province on January $23^{r d} 2020$. All shopping malls, parks, restaurants, schools, colleges, universities, cinema theatres, and industries were also shut down from the public. Inter- and intra-city transport in China were limited, and internationals were only allowed to be evacuated from the country after proper screening and procedures. People were instructed to stay at home and use masks ${ }^{6}$. The consumption of wild animals as food, and their import and export was completely banned. During the lock-down, the Chinese government provided food and every other basic need to their nationals on their doorsteps, and free electricity was provided to them. Free masks and sanitizers were also provided to the people.

The half-life of SARS-CoV-1 and SARS-CoV-2 are very similar; the aerosol emitted humans containing the virus can stay up to 1.2 hours. The halflife of SARS-CoV-2 depends on the material; it can stay active on steel for 5.9 hours and on plastic for 6.7 hours ${ }^{45}$. Therefore, the Chinese authorities washed the entire Wuhan city with alcohol to eradicate virus present on surfaces which efficiently reduced viral spreading. Now, China has completely defeated COVID-19; since the $25^{\text {th }}$ of March the Hubei Province has re-opened ${ }^{46}$.

\section{Therapeutic Strategies}

Currently, there is no approved antiviral drug and vaccine available to treat COVID-19, although Chinese doctors and researchers tried several other strategies which successfully reduced the viral load and infection. Immunity-boosting medications and probiotics were provided to patients and healthy individuals to boost up their immune system. Previouslyused broad spectrum antibiotics and antiviral drugs, in combination with inhibitors and interferons, were applied and resulted in reduction of viral load. It was reported that Remdisivir (an antiviral drug), in combination with interferons or other drugs like hydroxychloroquine, significantly blocked the viral replication $^{47}$. Traditional Chinese Medicines (TCM) are widely using against various diseases in Asia and other regions in the world. Many patients have also recovered from COVID-19 by the frequent use of $\mathrm{TCM}^{35,48}$. The plasma derived from patients who have recovered from COVID-19 was also used for the treatment of infected patients and showed significant results in recovery ${ }^{49}$. 

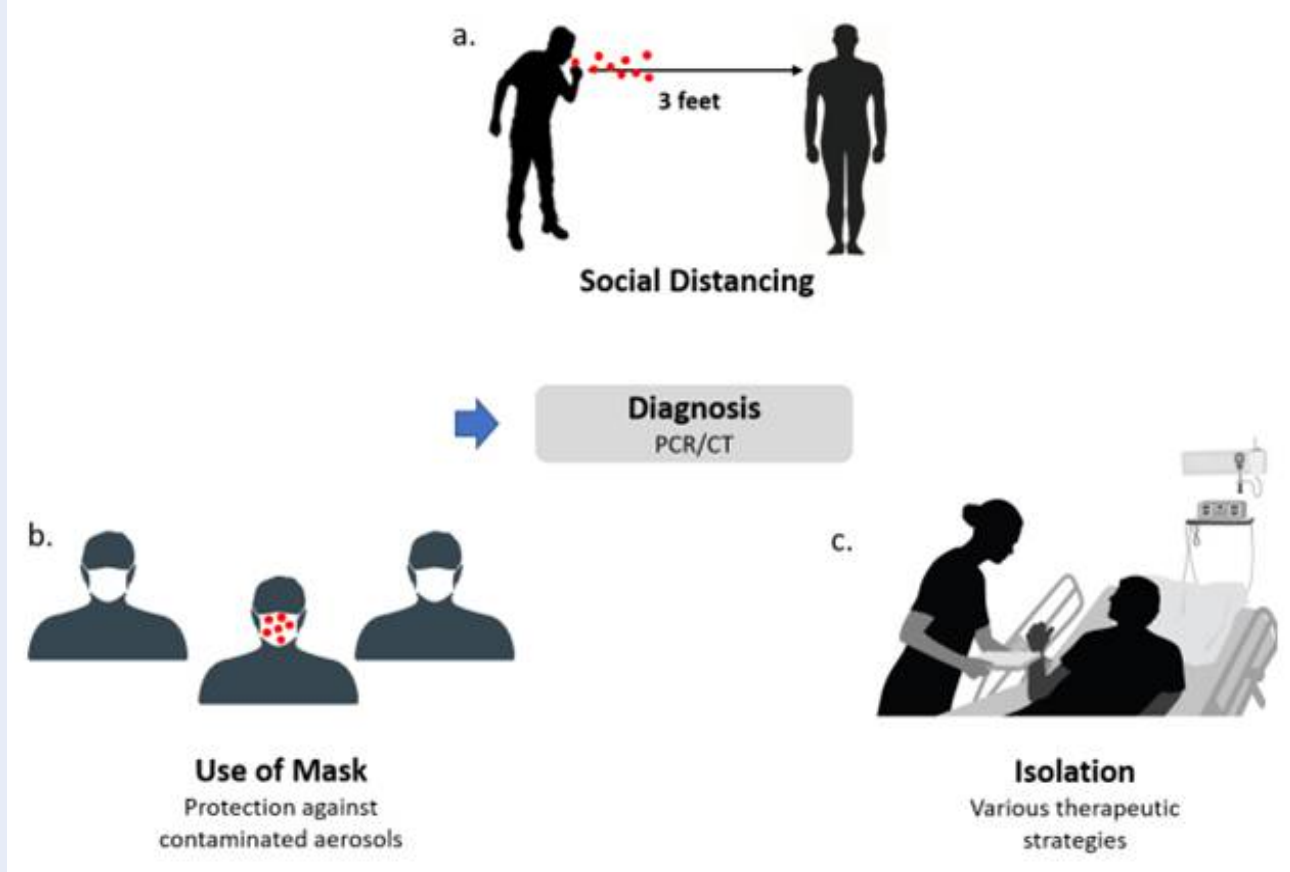

Figure 2: The strategies applied by Chinese health workers to contain and treat COVI19. (A) Social distancing: to avoid contact with infected or suspected person, minimum 3 feet distance was instructed. (B) Use of face mask to avoid the spreading of virus containing aerosols (red dots are shown as virus containing aerosols). (C) Immediate isolation and treatment of COVID-19 patient and quarantining suspected individuals.

\section{CONCLUSION AND FUTURE PERSPECTIVES}

The Chinese authorities have put great efforts in the timely and efficient response to the SARS-CoV-2 outbreak. They have limited the mortality rate to only $4 \%$, with numerous patients discharged after clinical recovery. China has set an example for the rest of the world. They have developed therapeutic strategies by using their traditional Chinese medicines, several drugs in combination, and immune boosters. COVID-19 is completely controlled in China with no new cases being reported, but COVID-19 is at its peak in Europe and the United States these days, with about $500+$ fatalities each day. Italy, Spain and Germany are the most affected countries in Europe, and perhaps they must follow the strategies of China to cope with COVID-19. Infected countries must impose a strict lock down and start door-to-door rapid screening and immediate isolation of suspected patients. It is suggested to build isolation and quarantine wards for infected and suspected patients near the borders and airports to restrict infected folks from entering the main populated cities. On the other hand, developing countries like Pakistan, Bangladesh, India and
Iran are at high risk and should use their all resources to mitigate COVID-19 by any means. Higher authorities of infected countries must take serious action in conducting awareness campaigns to educate their nationals on how best to protect themselves. It is difficult for such countries to conduct a lock down nationwide for a couple of months due to poverty and health resources.

There are 40 different strains of SARS-CoV-2 identified in various regions of the world which have adapted themselves to environmental and immunological conditions. The mutated strains have limited the recovery rate of COVID-19 in Europe and the US. Thus, it is important to develop a vaccine or a broadspectrum therapeutic strategy which can combat all these strains. There are some countries that are safe from the pandemic, where no or few COVID-19 cases are being reported; these countries include North Korea and countries in Africa. It is likely that previouslyused vaccines against other viruses are responsible for cross-resistance against COVID-19 or the strains are not adapted to these regions of the world. Isolated plasma from people of these regions may have the potential to treat COVID-19. 


\section{ABBREVIATIONS}

BCG Vaccine: Bacillus Calmette-Guérin Vaccine COVID-19: Disease-2019

SARS-CoV-2: Severe Acute Respiratory Syndrome Coronavirus-2

TCM: Traditional Chinese Medicine

UK: United Kingdom

USA: United States of America

WHO: World Health Organization

\section{ACKNOWLEDGMENTS}

Authors are thankful to the State Key Laboratory of Virology, College of Life Sciences, Wuhan University.

\section{AUTHOR'S CONTRIBUTIONS}

Muhammad Adnan Shereen (M.A.S), Abeer Kazmi (A.K), Hafiz Ullah (H.U), and Suliman Khan (S.K) are the leading authors. All the authors made substantial contributions to conception and design, acquisition of data, or analysis, and interpretation of data; took part in drafting the article or revising it critically for important intellectual content; gave final approval of the version to be published; and agree to be accountable for all aspects of the work.

\section{FUNDING}

Not applicable.

\section{AVAILABILITY OF DATA AND MATERIALS}

Data and materials used and/or analyzed during the current study are available from the corresponding author on reasonable request.

\section{ETHICS APPROVAL AND CONSENT TO PARTICIPATE}

Not applicable.

\section{CONSENT FOR PUBLICATION}

Not applicable.

\section{COMPETING INTERESTS}

The authors declare that they have no competing interests.

\section{REFERENCES}

1. Wang C, Horby PW, Hayden FG, Gao GF. A novel coronavirus outbreak of global health concern. The Lancet. 2020;Available from: https://doi.org/10.1016/S0140-6736(20)30185-9.

2. Phan LT, Nguyen TV, Luong QC, Nguyen TV, Nguyen HT, Le $\mathrm{HQ}$, et al. Importation and human-to-human transmission of a novel coronavirus in Vietnam. New England Journal of Medicine. 2020;PMID: 31991079. Available from: https://doi. org/10.1056/NEJMc2001272.
3. Riour J, Althaus CL. Pattern of early human-to-human transmission of Wuhan 2019 novel coronavirus (2019-nCoV), December 2019 to January 2020. Eurosurveillance. 2020;25(4). PMID: 32019669. Available from: https://doi.org/10.2807/ 1560-7917.ES.2020.25.4.2000058.

4. Parry J. China coronavirus: cases surge as official admits human to human transmission. British Medical Journal Publishing Group. 2020;PMID: 31959587. Available from: https: //doi.org/10.1136/bmj.m236.

5. Li Q, Guan X, Wu P, Wang X, Zhou L, Tong Y, et al. Early transmission dynamics in Wuhan, China, of novel coronavirusinfected pneumonia. New England Journal of Medicine. 2020;

6. Shereen MA, Khan S, Kazmi A, Bashir N, Siddique R. COVID-19 infection: origin, transmission, and characteristics of human coronaviruses. Journal of Advanced Research. 2020;PMID: 32257431. Available from: https://doi.org/10.1016/j.jare.2020. 03.005 .

7. Worldometer. COVID-19 coronavirus pandemic. 2020 [cited 202022 march];Available from: https://www.worldometers. info/coronavirus/.

8. Worldometer. COVID-19 CORONAVIRUS PANDEMIC. 2020 [cited 2020 23rd July];

9. AlJazeera. Coronavirus: Inside Pakistan's Taftan quarantine camp. 2020 [cited 202024 March];Available from: https://www.aljazeera.com/programmes/newsfeed/ 2020/03/coronavirus-pakistan-taftan-quarantine-camp200323110255493.html.

10. Khan S, Siddique R, Ali A, Xue M, Nabi G. Novel coronavirus, poor quarantine, and the risk of pandemic. Journal of Hospital Infection. 2020;PMID: 32057788. Available from: https://doi. org/10.1016/j.jhin.2020.02.002.

11. Team TIE. Kerala Defeats Coronavirus; India's Three COVID-19 Patients Successfully Recover. India news2020 [cited 20204 April];Available from: https://weather.com/en-IN/india/news/ news/2020-02-14-kerala-defeats-coronavirus-indias-threecovid-19-patients-successfully.

12. Tuite AR, Bogoch I, Sherbo R, Watts A, Fisman DN, Khan K. Estimation of COVID-2019 burden and potential for international dissemination of infection from Iran. medRxiv. 2020;Available from: https://doi.org/10.1101/2020.02.24.20027375.

13. Arab-Mazar Z, Sah R, Rabaan AA, Dhama K, Rodriguez-Morales AJ. Mapping the incidence of the COVID-19 hotspot in Iran-Implications for Travellers. Trav Med Infect Dis. 2020;p. 101630. PMID: 32184130. Available from: https://doi.org/10. 1016/j.tmaid.2020.101630.

14. Lillie PJ, Samson A, Li A, Adams K, Capstick R, Barlow GD, et al Novel coronavirus disease (Covid-19): the first two patients in the UK with person to person transmission. Journal of Infection. 2020;PMID: 32119884. Available from: https://doi.org/10. 1016/j.jinf.2020.02.020.

15. Bordi L, Nicastri E, Scorzolini L, Caro A, et al. Differential diagnosis of illness in patients under investigation for the novel coronavirus (SARS-CoV-2), Italy, February 2020. Eurosurveillance. 2020;25(8). Available from: https://doi.org/10.2807/ 1560-7917.ES.2020.25.8.2000170

16. Moritsugu K, Miller Z. Things You Should Know About the Novel Coronavirus China Is "The Central Threat": Pompeo| Coronavirus Doctors Targeted! Death toll continues to rise in China as countries scramble to tackle coronavirus outbreak 11 confirmed US coronavirus cases, experts warn of pandemic| $A B C$ News Coronavirus Outbreak: Interview with Anthony Fauci, National Institute of Health. 2020;Available from: https: //pronkpops.wordpress.com/category/politics/elections/.

17. Holshue ML, DeBolt C, Lindquist S, et al. First case of 2019 novel coronavirus in the United States. New England Journal of Medicine. 2020;PMID: 32004427. Available from: https:// doi.org/10.1056/NEJMoa2001191.

18. Times TNY. White House Projects Grim Toll From Coronavirus 2020 [cited 20203 April];Available from: https://www.nytimes. com/2020/03/31/world/coronavirus-live-news- updates.html. 
19. Choi M. Trump suggests wearing a scarf against coronavirus. The CDC isn't so sure. Politico2020 [cited 2020 11 April];Available from: https://www.politico.com/news/2020/ 04/01/trump-scarf-coronavirus-mask- 160589.

20. Harris K. Sophie Grégoire Trudeau tests positive for coronavirus. CNN2020 [cited $2020 \quad 4$ April];Available from: https://www.cbc.ca/news/politics/covid19-premierscoronavirus- 1.5495001 .

21. Guzman J. Could coronavirus (COVID-19) mutate into a new strain? 2020 [cited 202024 March];Available from: https: //thehill.com/changing-america/well-being/prevention-cures/ 485972-the-novel-coronavirus-is- mutating-as-scientists.

22. Tang $X, W u C$, et al. On the origin and continuing evolution of SARS-CoV-2. National Science Review. 2020;Available from: https://doi.org/10.1093/nsr/nwaa036.

23. Farber M. Coronavirus has mutated at least once, second strain detected: study. [cited 202024 March]. 2020;Available from: https://www.foxnews.com/health/coronavirus-hasmutated-at-least-once-second-strain-detected-study.

24. Ramesh S. How the novel coronavirus is mutating, and if you should be concerned. The Print2020 [cited 2020 5 April];Available from: https://theprint.in/science/howthe-novel-coronavirus-is- mutating-and-if-you-should-beconcerned/391860/.

25. Nafie M. Coronavirus mutates into 40 strains. How this changes the pandemic outlook: Experts. Alarabiya English 2020 [cited $2020 \quad 5$ April];Available from: https://english.alarabiya.net/en/features/2020/03/27/ Coronavirus-mutates-into- 40 - strains-How-this-changes- thepandemic-outlook-Exp.

26. Miller A, Reandelar MJ, Fasciglione K, Roumenova V, Li Y, Otazu GH. Correlation between universal BCG vaccination policy and reduced morbidity and mortality for COVID-19: an epidemiological study. medRxiv. 2020;Available from: https: //doi.org/10.1101/2020.03.24.20042937.

27. Sheahan TP, Sims AC, Leist SR, Schäfer A, et al. Comparative therapeutic efficacy of remdesivir and combination lopinavir, ritonavir, and interferon beta against MERS-CoV. Nature communications. 2020;11(1):1-14. PMID: 31924756. Available from: https://doi.org/10.1038/s41467-019-13940-6.

28. Richardson P, Griffin I, Tucker C, Smith D, Oechsle O, Phelan A. Baricitinib as potential treatment for 2019-nCoV acute respiratory disease. The Lancet. 2020;Available from: https: //doi.org/10.1016/S0140-6736(20)30304-4.

29. Daily C. 6 effective TCM recipes for COVID-19. 2020 [cited 2020 April];Available from: http://covid-19.chinadaily.com.cn/ a/202003/24/WS5e795bb6a3101282172816c2.html.

30. Han Y, Zhao M, Shi B, Song Z, Zhou S, He Y. Application of integrative medicine protocols on treatment of coronavirus disease 2019. Chin Tradit Herb Drugs. 2020;p. 02-18.

31. Inovio IP. Inovio selected by cepi to develop vaccine against new coronavirus inovio. 2020 [cited 202029 January];Available from: http://ir.inovio.com/news-and-media/ news/press-release-details/2020/Inovio-Selectedby-CEPI- toDevelop-Vaccine-Against-NewCoronavirus/default.aspx.

32. Johnson J. Our COVID-19 Response Efforts. 2020 [cited 2020 17 April];Available from: https://www.jnj.com/coronavirus.

33. Dong L, Hu S, Gao J. Discovering drugs to treat coronavirus disease 2019 (COVID-19). Drug discoveries \& therapeutics. 2020;14(1):58-60. PMID: 32147628. Available from: https: //doi.org/10.5582/ddt.2020.01012.

34. Gao Q, Bao L, et al. Rapid development of an inactivated vaccine for SARS-CoV-2. bioRxiv. 2020;Available from: https: //doi.org/10.1101/2020.04.17.046375
35. Shereen MA, Kazmi A. SARS-CoV-2 pandemic: causes and current situation, historical lessons, and strategical therapeutic interventions. Biomedical Research and Therapy. 2020;7(5):3807-3812. Available from: https://doi.org/10 15419/bmrat.v7i5.608.

36. Corum J. Coronavirus Vaccine Tracker. The New York Times; 2020 [cited 2020 24th July];Available from: https://www.nytimes.com/interactive/2020/science/ coronavirus-vaccine-tracker.html.

37. Craven J. COVID-19 vaccine tracker. Regulatory Focus; 2020 [cited 2020 23rd July];Available from: https://www.raps.org/news-and-articles/news-articles/2020/3/ covid-19-vaccine-tracker.

38. Mestrovic T. PiCoVacc vaccine candidate for COVID19 effective in animal trials. News Medical Life Sciences; [cited 2020 May]. 2020;Available from: https: //www.news-medical.net/news/20200421/PiCoVacc-vaccinecandidate-for-COVID-19-effective-in-animal-trials.aspx.

39. Cai $Y$, Huang T, Liu X X X G. The Effects of" Fangcang, Huoshenshan, and Leishenshan" Makeshift Hospitals and Temperature on the Mortality of COVID-19. medRxiv. 2020;Available from: https://doi.org/10.1101/2020.02.26.20028472.

40. Caiab Y, Huanga T, Liua X, Xua G. The Effects of "Fangcang, Huoshenshan, and Leishenshan" Hospitals and Temperature on the;

41. Zhang S, Diao MY, Duan L, Lin Z, Chen D. The novel coronavirus (SARS-CoV-2) infections in China: prevention, control and challenges. Intensive Care Medicine. 2020;p. 1-3. PMID: 32123989. Available from: https://doi.org/10.1007/s00134020-05977-9.

42. Hunter P. The spread of the COVID-19 coronavirus. EMBO reports. 2020;

43. Jia $X$, Zhang $P$, et al. Clinical significance of IgM and IgG test for diagnosis of highly suspected COVID-19 infection. medRxiv. 2020;Available from: https://doi.org/10.1101/2020. 02.28 .20029025 .

44. Suo T, Liu X. ddPCR: a more sensitive and accurate tool for SARS-CoV-2 detection in low viral load specimens. medRxiv. 2020;Available from: https://doi.org/10.1101/2020. 02.29.20029439.

45. Doremalen N, Bushmaker T, Morris DH, Holbrook MG, Gamble A, Williamson BN. Aerosol and Surface Stability of SARSCoV-2 as Compared with SARS-CoV-1. New England Journal of Medicine. 2020;Available from: https://doi.org/10.1101/2020. 03.09.20033217.

46. Wong S, Vaughan A, Quilty-Harper C, Liverpool L. Coronavirus latest news: Wuhan plans to end lockdown in April. 2020 [cited 202024 March];Available from: https://www.newscientist.com/article/2237475-coronaviruslatest-news-wuhan-plans-to-end-lockdown-in-april/.

47. Wang $M$, Cao R, Zhang L, Yang $X$, et al. Remdesivir and chloroquine effectively inhibit the recently emerged novel coronavirus (2019-nCoV) in vitro. Cell Research. 2020:1-3. ;PMID: 32020029. Available from: https://doi.org/10.1038/s41422020-0282-0.

48. Wang Z, Li L, Yan J, Yao Y. Evaluating the Traditional Chinese Medicine (TCM) Officially Recommended in China for COVID19 Using Ontology-Based Side-Effect Prediction Framework (OSPF) and Deep Learning. 2020;Available from: https://doi. org/10.20944/preprints202002.0230.v1.

49. Derebail VK, Falk RJ. ANCA-Associated Vasculitis-Refining Therapy with Plasma Exchange and Glucocorticoids. Mass Medical Soc. 2020;Available from: https://doi.org/10.1056/ NEJMe1917490PMid:32053306. 